\title{
Vegetation of the Owen Sitole College of Agriculture in Zululand, KwaZulu-Natal
}

\author{
J.P. VAN der Linden, S.J. Siebert, F. Siebert, D.P. Ferreira and G.J. BREdenKaMP
}

Van der Linden, J.P., S.J. Siebert, F. Siebert, D.P. Ferreura and G.J. Bredenkamp. 2005. Vegetation of the Owen Sitole College of Agriculture in Zululand, KwaZulu-Natal. Koedoe 48(1): 33-56. Pretoria. ISSN 0075-6458.

A vegetation survey was conducted of the Owen Sitole College of Agriculture (OSCA). Phytosociological data were used to identify plant communities and to determıne alpha diversity. Five plant communities were recognised and described. One of these was subdivided into two sub-communities. An ordination scatter diagram of the distribution of the six vegetation units depicted topographically induced gradients, specifically related to soil depth, rock cover, slope and altitude. Floristic composition of the six vegetation units indicates that this coastal thornveld has affinities to the Grassland, Savanna and Forest biomes. In the study area, closed woodland communities have the highest plant richness and grassland communities the highest plant diversity. Diversity and richness per community compares favourable with the Rocky Highveld Grassland, suggesting that phytodiversity at OSCA was maintained despite a history of multiple disturbances. The habitat on OSCA farm serves as an important refuge for plant species and communities of biological and economic significance, especially the remaining grasslands.

Key words: biodiversity, conservatıon, forest, grassland, phytosociology, species richness, savanna, thornveld.

JP. Van der Linden. SJ Siebert. F Siebert, D P Ferreira, Department of Botany; Linversity of Zululand, Private Bag X1001. KwaDlangezwa. 3886 Republic of South Africa: G.J Bredenkamp. African Vegetation \& Plant Diversity Research Centre, Department of Botany; University of Pretoria, Pretoria, 0002 Republic of South Africa

\section{Introduction}

KwaZulu-Natal is a region of cultural significance and conservation importance (Goodman et al. 2002; Hughes 2002). However, development and its associated ecological footprint are exerting increasing pressure on the environment and are fast leading to dwindling natural resources due to habitat loss (Scott-Shaw 1999; Roberts et al. 2002). In Zululand, sugarcane and timber plantations, agricultural monocultures and rural housing developments, all contribute to the formation of fragmented patches of natural vegetation. Habitat fragmentation could result in a decrease in community species richness and even species extinction, caused by decreased chances of seed dispersal and lack of suitable habitat for re-colonisation (With \& King 1999; Bruun 2000).
Loss of plant diversity in natural areas in South Africa will be to the detriment of subsistence farmers and other poor rural people, as these people are dependant on natural resources for their livelihoods and health (Hutchings 1996; Van Wyk \& Gericke 2000). Large tracts of undisturbed land outside parks and reserves with rich ethnobotanical resources are limited and sustainable use of such resources has now become important. Many of these plant resources are small wild flowers and there is no management plan for KwaZulu-Natal to conserve plants of fragmented areas that are extensively used for food and medicine by local communities (Scott-Shaw 1999).

Considering the above, the role of small, fragmented areas as natural resource reserves could become significant in maintaining endangered plant diversity. As a step forward, an inventory must be compiled of plant 


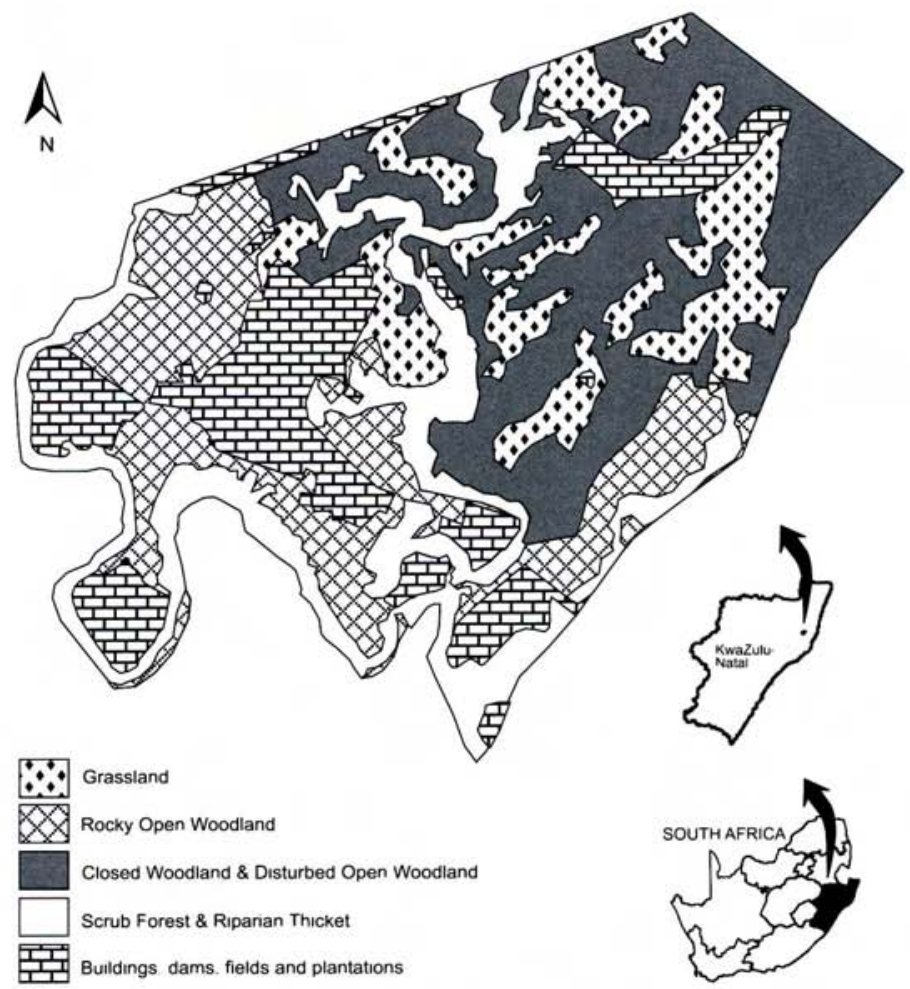

Fig. 1. Vegetation map of the Owen Sitole College of Agriculture.

community composition and species distribution of small fragmented conservation areas (Smit et al. 1997; Siebert et al. 2003). The aims of this study are therefore to identify the plant communities, classify the vegetation, relate these to specific environmental factors, and to assess the plant diversity on the Owen Sitole College of Agriculture (OSCA) farm for future land-use planning and management (Foran et al. 1986; Kent \& Ballard 1988).

\section{Study area}

The Owen Sitole College of Agriculture is situated $12.5 \mathrm{~km}$ north of Empangeni on the old Mtubatuba road. The 672 ha farm averages $3.2 \mathrm{~km}$ in width from east to west and $2.2 \mathrm{~km}$ from north to south. The area extends from latitudes $28^{\circ} 57^{\prime} 45^{\prime \prime}-28^{\circ} 57^{\prime} 22^{\prime \prime} \mathrm{S}$ and between longitudes $31^{\circ} 55^{\prime} 31^{\prime \prime}-31^{\circ} 57^{\prime} 22$ "E. The farm borders on the old EmpangeniMtubatuba road in the east and the Nseleni River in the south (Fig. 1).

The farm was acquired from the Mthethwa Tribe in Reserve 5, Lower Umfolozi District, currently known as the Enseleni District. The land was obtained in exchange for a portion of State Land in the same district. The College was established in 1968 to train Zulu people in agriculture, animal health and nature conservation. During its inception it was named the Cwaka Agricultural College after the Cwaka River which runs through the property from northwest to southeast. In 1985 the College was renamed the Owen Sitole College of Agriculture in honour of the late Inkosi Owen Sitole. 
Land-use in the surrounding areas comprises subsistence farming, forestry and sugarcane. The result of these practices was that natural vegetation remained only in small, isolated patches in the landscape. Within OSCA, numerous shifts in land use since the 1930s have also significantly contributed to the loss of pristine pastures in the study area. Changes in land use and the response of the natural vegetation can be followed through a series of aerial photographs that date from 1937 (Van der Linden 2004). These photographs show that the land of OSCA was open grassland during the 1930s and early 1940 s. During the late 1940 s, subsistence farmers began to cultivate large parts of the land. This resulted in overgrazing of the remaining pastures. This continued at irregular intervals and intensity up to 1968 , when the subsistence farmers received new land and the land was incorporated under OSCA. Between 1968 and 2003, agricultural activities continued and became more intense to serve the needs of the College (Van der Linden 2004).

The landscape consists of a series of undulating hills sloping down to the floodplains of the Nseleni and Cwaka Rivers. Altitude varies from $23 \mathrm{~m}$ above sea level at the lowest point in the valley of the Nseleni River, to $120 \mathrm{~m}$ on hills in the northwestern portion of the farm. The Cwaka River, which flows from the north into the Nseleni River, divides the farm into two almost equal sized parts.

The mean annual rainfall for OSCA is $1022 \mathrm{~mm}$ (AGROMET 2002), with a third of the rain falling in mid to late summer (January to March). Rain falls throughout the year, but drier spells are experienced during the winter months. Mean day temperature range from a minimum of $19^{\circ} \mathrm{C}$ in winter to $33^{\circ} \mathrm{C}$ in summer. The mean annual temperature is $26^{\circ} \mathrm{C}$ (AGROMET 2002).

The uppermost group of the Karoo Sequence underlies the study area, namely the southern limit of the volcanic basalts that belong to the Letaba Formation of the Lebombo Group (Visser et al. 1989). Flood plains and river
Table 1

Percentage cover of each soil form in the study area as well as the approximate area in hectare (ha)

\begin{tabular}{lcc}
\hline Soll Form & Cover (\%) & Area (ha) \\
\hline Mayo / Tambankulu & 68.9 & 454 \\
Oakleaf & 7.2 & 47 \\
Westleigh & 6.4 & 41 \\
Inhoek & 5.6 & 36 \\
Shortlands & 45 & 29 \\
Rensburg & 3.9 & 25 \\
Glenrosa & 1.8 & 12 \\
Willowbrook & 0.6 & 4 \\
Kroonstad & 0.2 & 1 \\
\hline
\end{tabular}

terraces are underlain by alluvium. Nine different soil forms occur in the study area, of which Mayo/Tambankulu is the most dominant (Table 1) (Van der Linden 2004).

OSCA falls within two Bio-Resource Units (BRU), namely Moist Coast Forest, Thorn and Palmveld (BRU 1) and Moist Zululand Thornveld (BRU 19) (Camp 2001). According to Acocks (1988), OSCA falls under Coastal Tropical Forest and is part of the Coastal Forest and Thornveld (Veld Type 1). More specifically it is described as the thornveld element of Typical Coast-belt Forest which is classified under Veld Type 1. Granger et al. (1996) places the study area under Coastal Bushveld-Grassland (Vegetation Type 23).

\section{Methods}

Sampling was done in 43 plots. OSCA farm was stratified into relatively homogeneous physıgraphic-physıgnomic units using 1:50 000 stereo aerial photographs. Plots were randomly placed within these stratıfication units, which represent different plant communities. Plot size was fixed at $20 \mathrm{~m}$ $\times 20 \mathrm{~m}$. Withın each sample plot, total floristıc composition was recorded and a cover-abundance value assigned to each species according to the BraunBlanquet scale (Mueller-Dombors \& Ellenberg 1974). Environmental factors were recorded and included aspect, altitude, soil type and soil depth, terrain type, rock cover, as well as fire and grazıng history. Vegetation structure was classified accord- 
ing to Edwards (1983) and is reflected in the names of the plant communities. Species names follow the annotated plant checklist of southern Africa (Germishuizen \& Meyer 2003). Plant growth forms are indicated next to species names in the phytosociological table.

Relevé data were stored and managed in the TURBOVEG (Hennekens 1996a) database and exported to MEGATAB (Hennekens 1996b) for multivariate analysis. A first approximation of a vegetation classification for OSCA was obtained by the application of TWINSPAN (Hill 1979a) to the total floristic data set. Braun-Blanquet procedures (Westhoff \& Van der Maarel 1978) were followed to refine the phytosociological table. Data were subjected to ordination to identify possible gradients between and within the recognised plant communities, and to relate community variation to environmental gradients. DECORANA (Hill 1979b) was applied to produce a scatter diagram of the relevés.

Alpha diversity (species richness) is defined as the number of species per unit area within a homogeneous plant community (Whittaker 1977). In this study the mean number of species per unit area was calculated from the total richness obtained for each plot of a plant community. Shannon-Wiener diversity indices were used to combine species richness and relative abundance among species (Barbour et al. 1997). In this study the Braun-Blanquet scale was converted to percentage cover, and the mean cover per species per plant community was taken as its abundance value.

Mean vegetation cover percentage (MCP) was determined for each species in each community. MCP is the sum of a species' percentage cover in all the relevés of a community, divided by the total number of relevés for that community (species cover was determined using the following conversion from the Braun-Blanquet scale: $r=0.5 \% ;+=1 \% ; 1=3 \% ; 2 \mathrm{a}$ $=8 \% ; 2 \mathrm{~b}=18 \% ; 3=37 \%$ ). Species were grouped into three main growth forms, namely trees (including shrubs), forbs (includes geophytes) and grasses. Total vegetation cover percentage (TCP) was determined by adding the MCPs for each growth form in each community. TCP is used to compare the dominance of different growth forms for each vegetation structure (Siebert et al. 2003).

\section{Results and discussion}

\section{Classification}

Results of the classification are presented in a dendrogram (Fig. 2) and a phytosociological table (Table 2). Data analyses resulted in the identification of five plant communities and two sub-communities. The vegetation of OSCA represents two distinctly different vegetation types, which were clearly separated by TWINSPAN. These are grouped as an open vegetation type with three plant communities, and closed vegetation type with two plant communities.

A. Acacia karroo-Themeda triandra Open Coastal Thornveld

1. Heteropogon contortus-Tephrosta bachmannii Grassland

2. Diheteropogon amplectens-Phoenix reclinata Open Woodland

2.1 Chloris gayana-Schinus terebinthifolius Disturbed Open Woodland

2.2 Trachypogon spicatus-Gymnosporia buxifolia Rocky Open Woodland

3. Acacia nilotica-Lantana rugosa Closed Woodland

B. Acacia karroo-Hippobromus pauciflorus Closed Coastal Thornveld

4. Asparagus falcatus-Trimeria grandifolia Scrub Forest

5. Commiphora harveyt-Cussonia zuluensis Riparian Thicket

\section{Description}

The vegetation of OSCA varies considerably, ranging from patches of short forest and thicket to short woodland and grassland (Edwards 1983), depending on specific environmental gradients (Fig. 3). Riparian Thicket and Scrub Forest occurs along most drainage lines and the low-lying valleys of the Cwaka and Nseleni rivers. The higher lying rangeland is a transition from sour to mixed veld. Forbs are common in the grass layer and include common species of the following genera: Berkheya, Cephalaria, Desmodium, Eriosema, Indigofera, Leonotis, Lippia, Nidorella, Senecio and Tephrosia. Dominant grass species include Cymbopogon nardus, Setaria sphacelata, Themeda triandra, Trachypogon spicatus and Tristachya leucothrix, with Panicum maximum dominant under trees. Dense stands of Hyparrhenia hirta occur on old cultivated fields. In slightly overgrazed areas Era- 


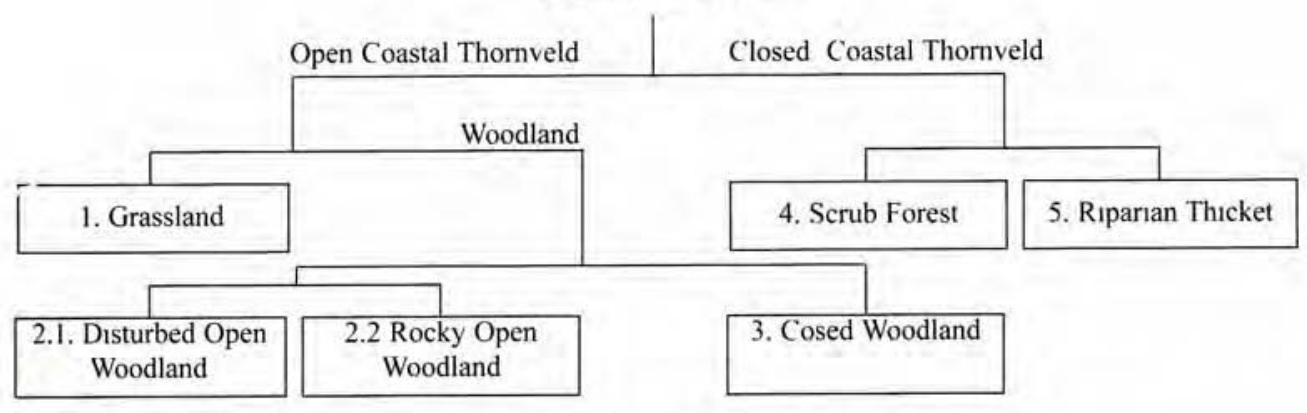

Fig. 2. A dendrogram is depicting the division of the vegetation in the study area.

grostis curvula and Sporobolus pyramidalis dominate the grass layer, but in severely overgrazed areas it is dominated by Aristida congesta. Common trees in the study area include Acacia karroo, Acacia nilotica, Apodytes dimidiata, Coddia rudis, Cussonia zuluensis, Dichrostachys cinerea, Gymnosporia senegalensis, Kraussia floribunda, Phoenix reclinata, Scutia myrtina and Trichilia emetica.

A. Acacia karroo-Themeda triandra Open Coastal Thornveld

This vegetation type covers the larger part of the study area $(>75 \%)$ and is associated with elevated areas on steep, rocky hills and open flats (Table 3). Most of the open, flat plains are overgrazed, regularly burnt and previously cultivated, whereas such disturbances are not common on the rocky hill slopes. The vegetation is part of Moist Coast Palmveld and Moist Zululand Thornveld (Camp 2001).

Diagnostic species are listed in species group $\mathrm{G}$ (Table 2). Diagnostic and dominant grass species that occur in most of the plant communities within this vegetation type include taxa such as Hyparrhenia hirta, Setaria nigrirostris, Themeda triandra and Tristachya leucothrix. Berkheya multijuga, Cycnium tubulosum, Xysmalobium undulatum, Vernonia oligocephala and Scabiosa columbaria (species groups $\mathrm{E}$ and $\mathrm{G}$ ) are the most prominent forb species, whereas Psidium guajava, an alien invasive from tropical
America, forms the diagnostic woody layer of the vegetation type. Dominant shrub and tree species include Gymnosporia senegalensis, Lippia javanica and Scutia myrtina (species groups $\mathrm{K}, \mathrm{N}$ and $\mathrm{O}$ ), and Acacia karroo, A. nilotica, Dichrostachys cinerea, Euclea racemosa, Kraussia floribunda, Phoenix reclinata and Rhus rehmanniana (species groups $\mathrm{N}$ and $\mathrm{O}$ ).

\section{Heteropogon contortus-Tephrosia bachmannu Grassland}

This community occurs mainly in the eastern part of the study area on flat to moderately steep $\left(6^{\circ}\right)$ terrain. The Mayo soil type dominates this rocky habitat, with depths ranging between 100-150 mm, and clay content of $45-60 \%$ (Table 3 ). This area has a history of frequent burns and was heavily grazed in the past. Erosion is common. Flat terrain on slightly deeper soils was previously cultivated.

Diagnostic species of the plant community is presented in species group A (Table 2) of which forb species such as Cephalaria pungens, Chamaecrista mimosoides, Eriosema cordatum and Tephrosia bachmannii, and grass species such as Aristida junciformis and Heteropogon contortus, are the most conspicuous. This community is characterised by the presence of a large number of geophytic species (18 taxa), including diagnostic species such as Albuca setosa, Gladi- 


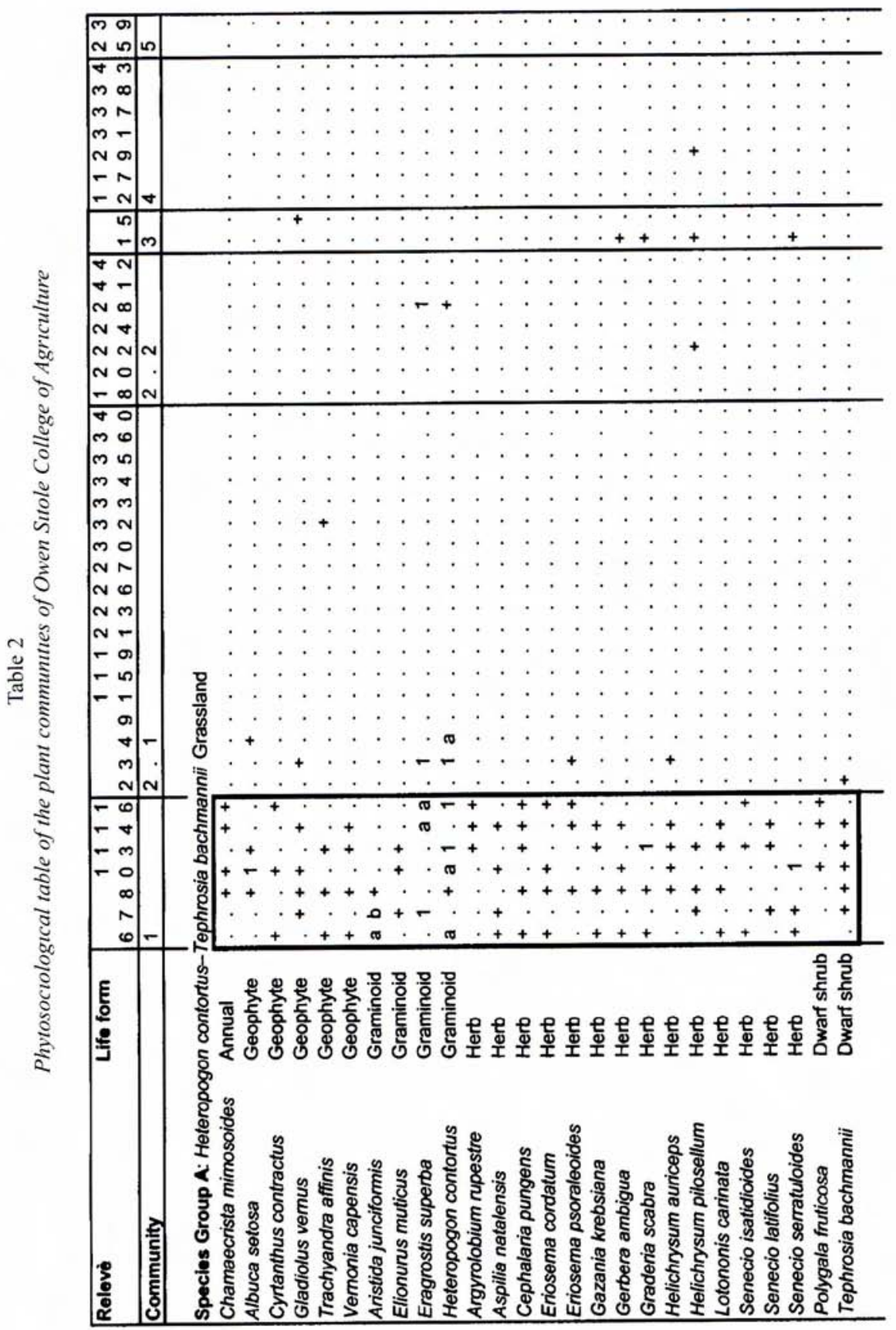




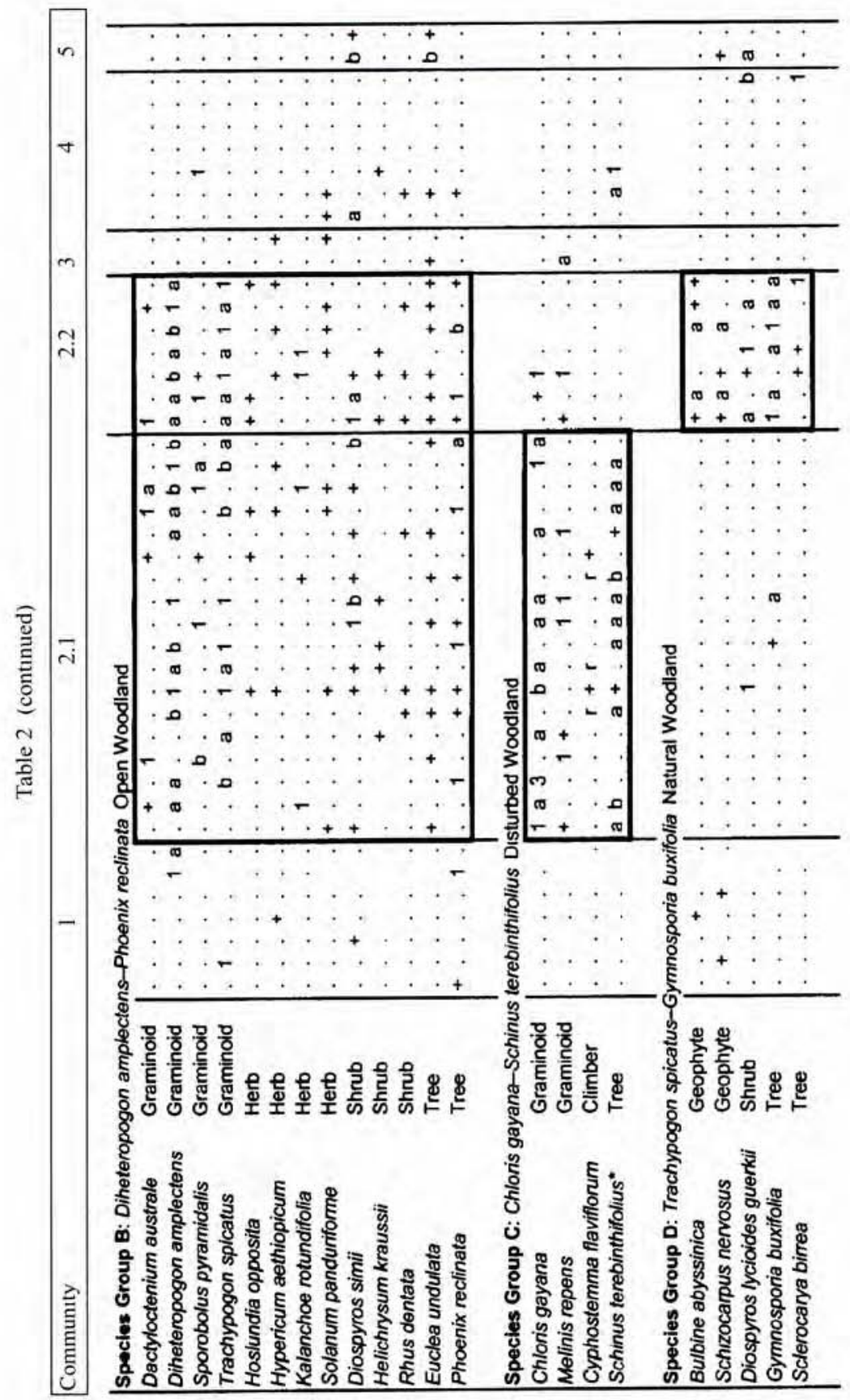




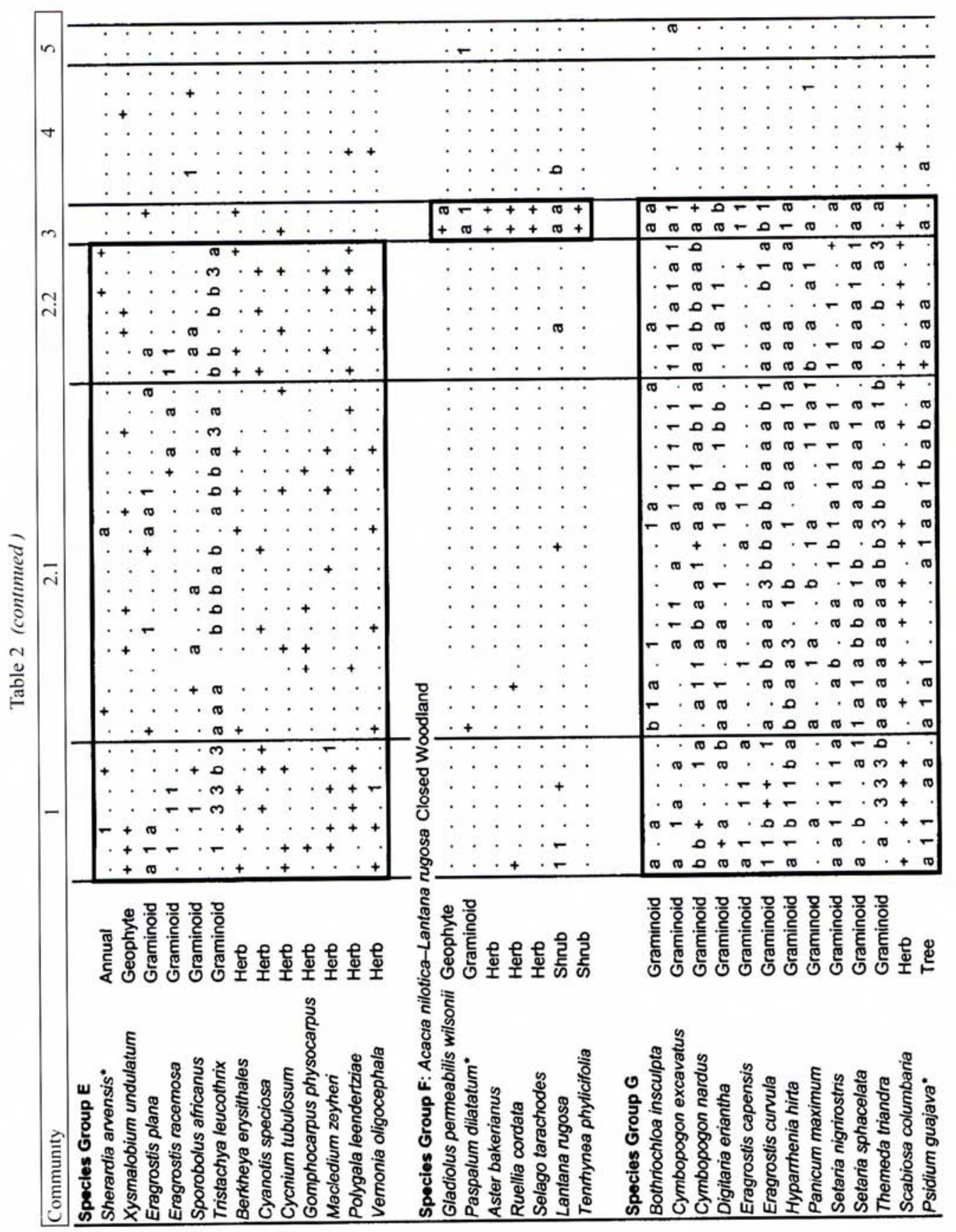




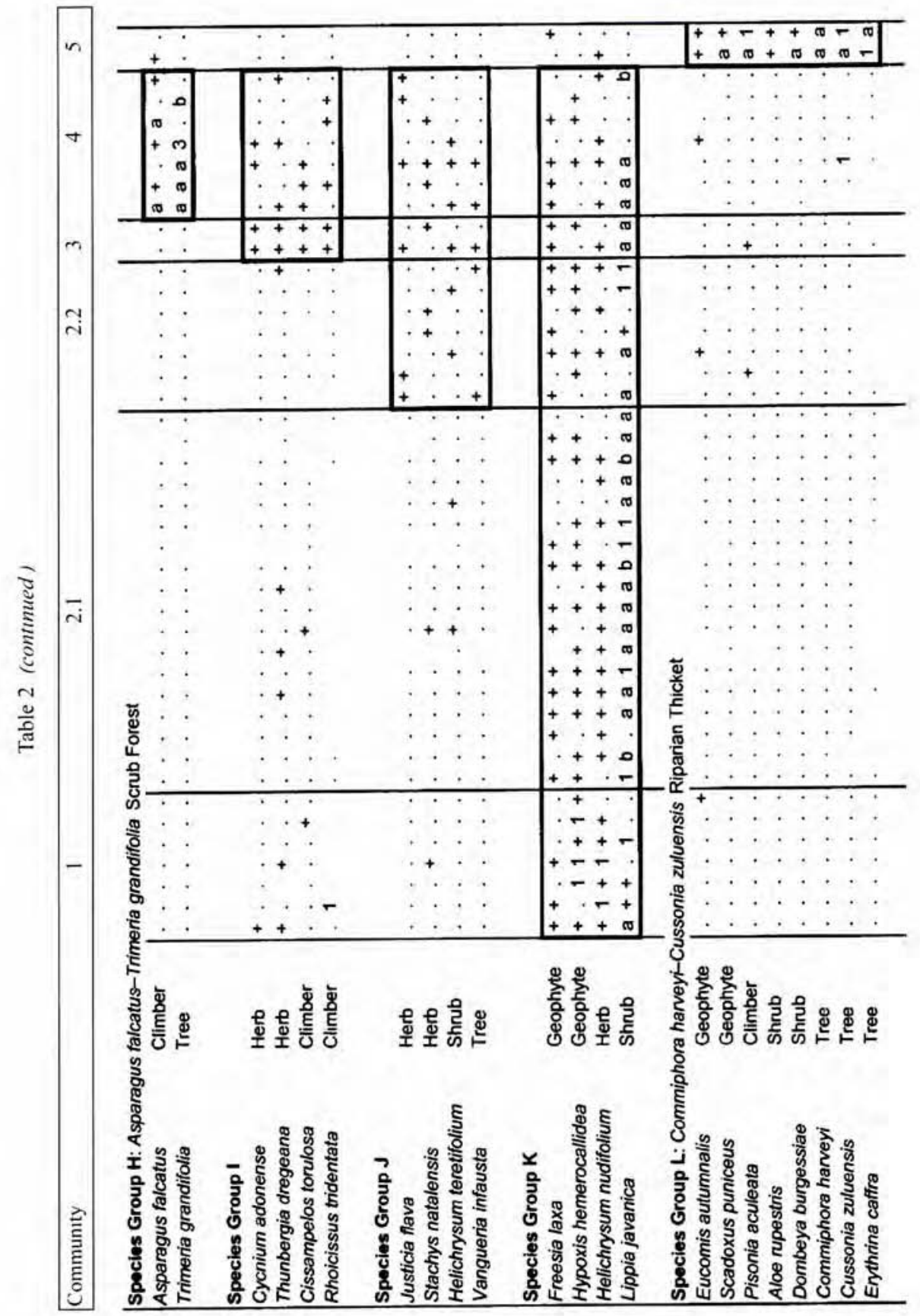




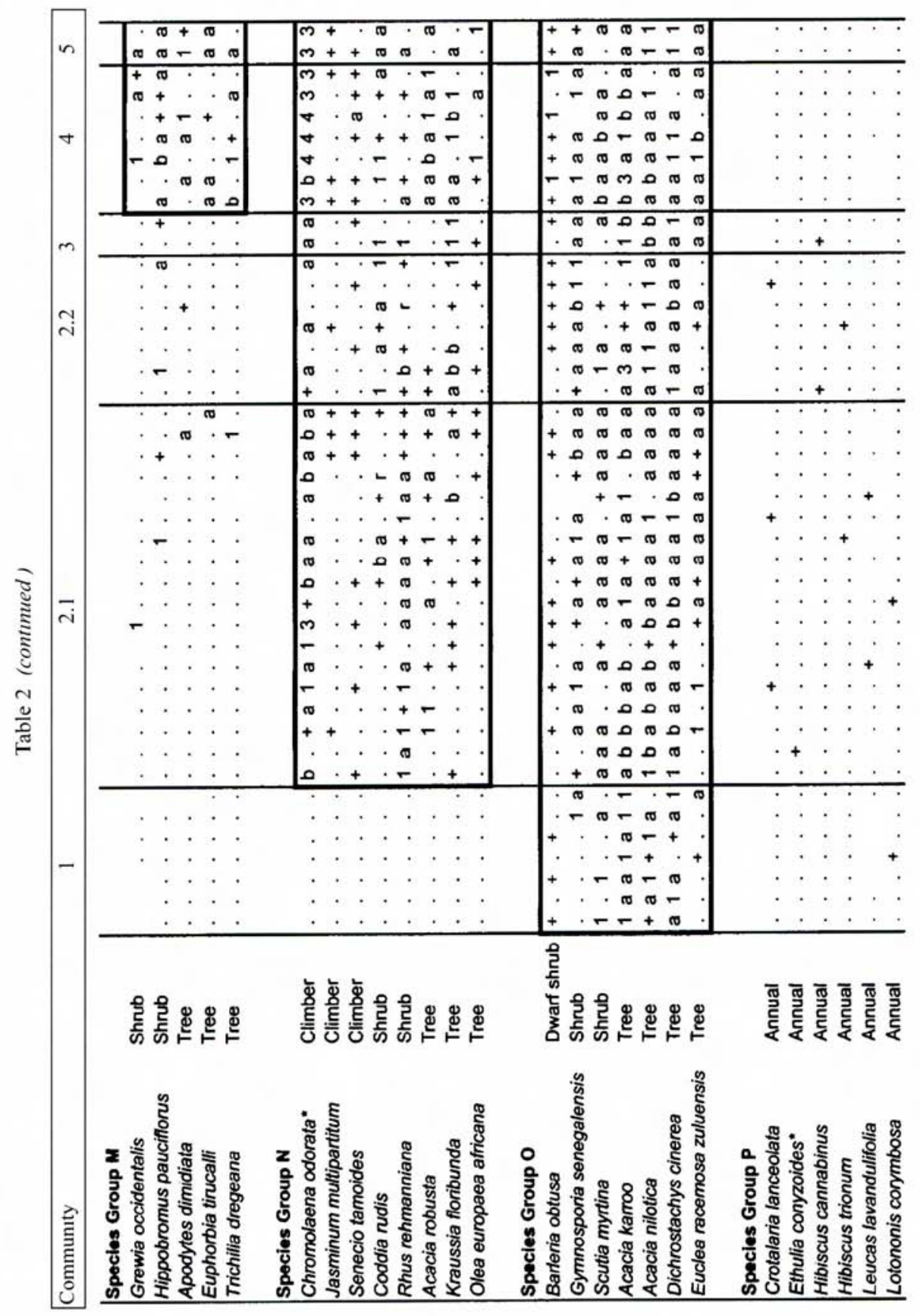




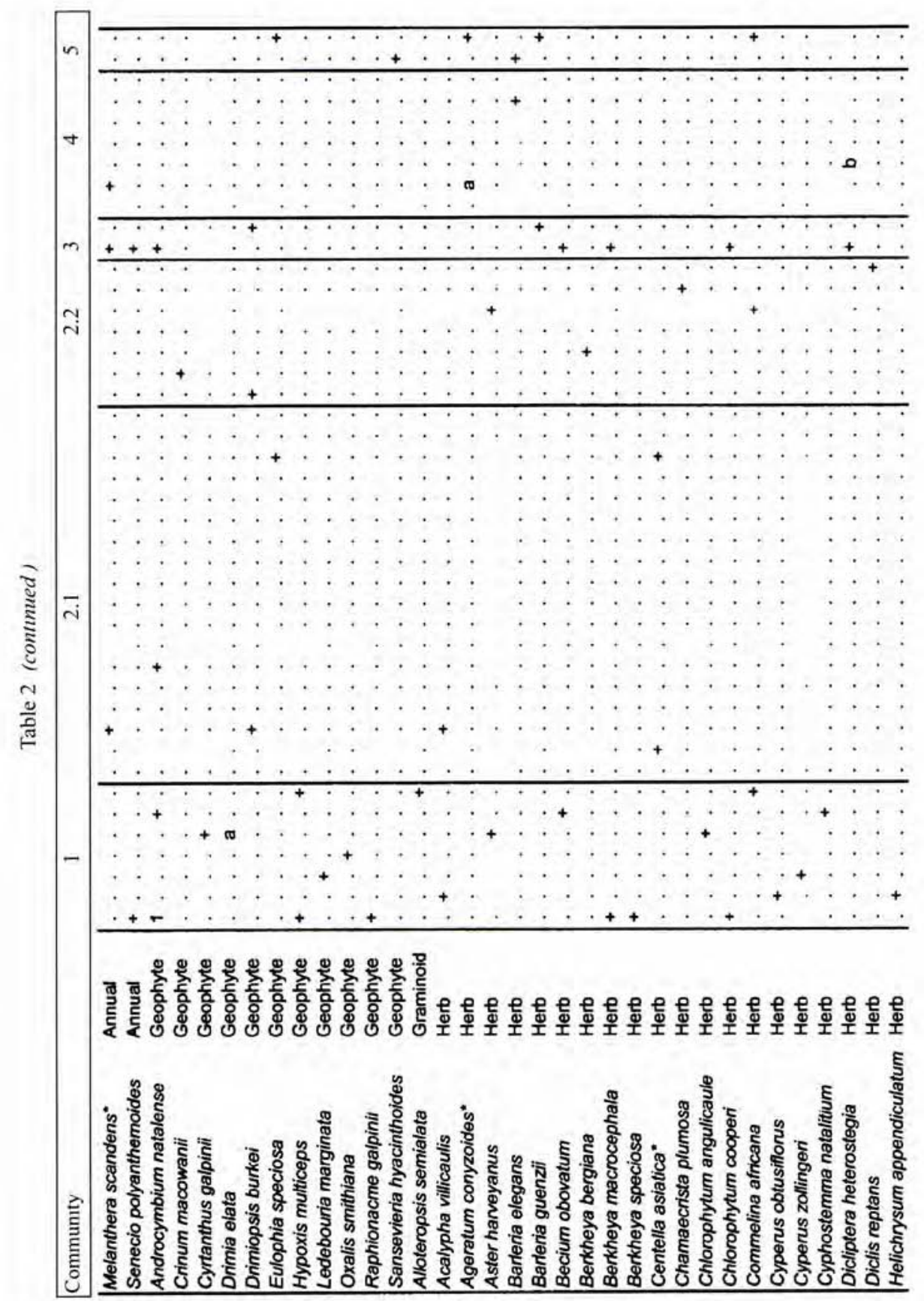




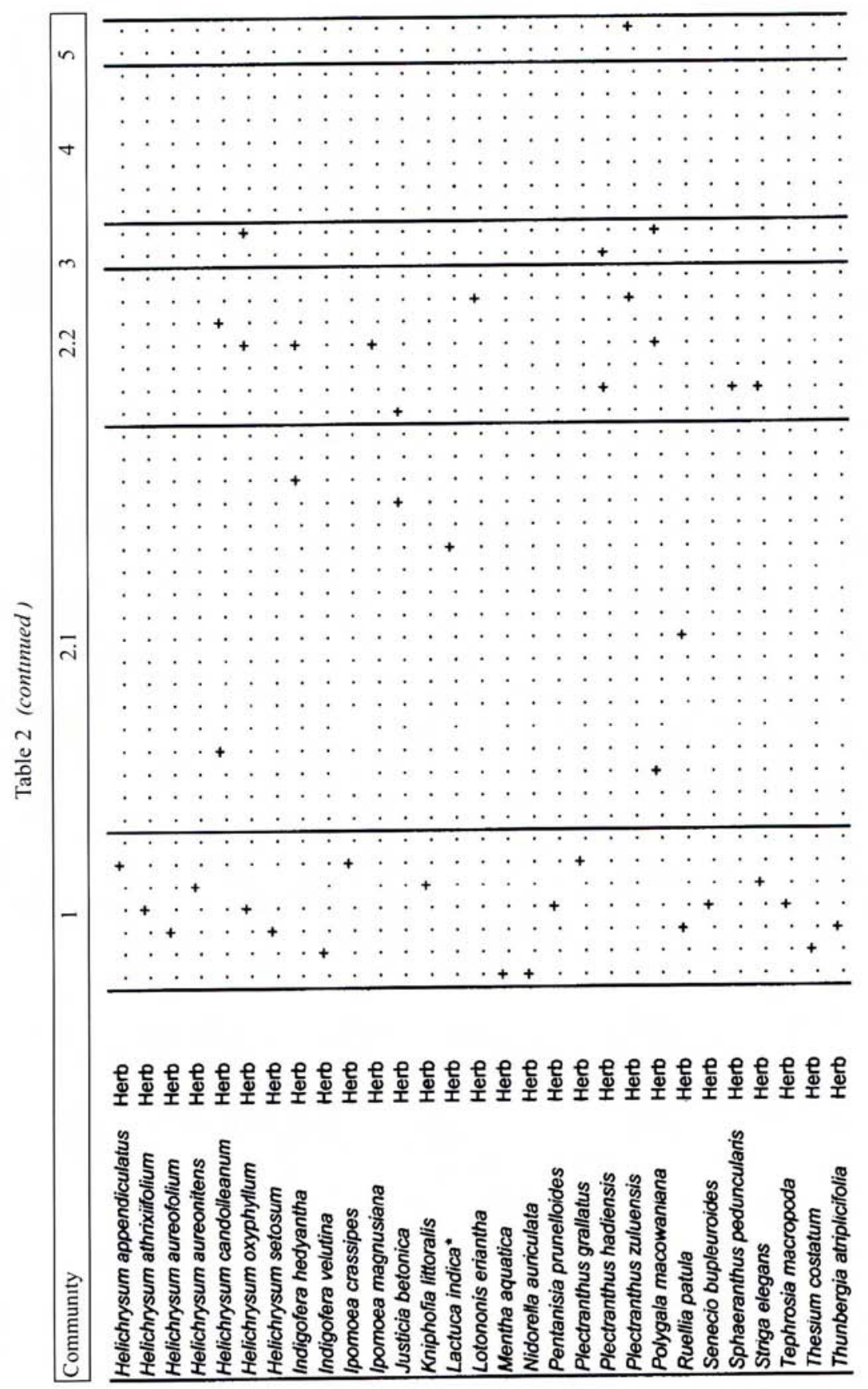




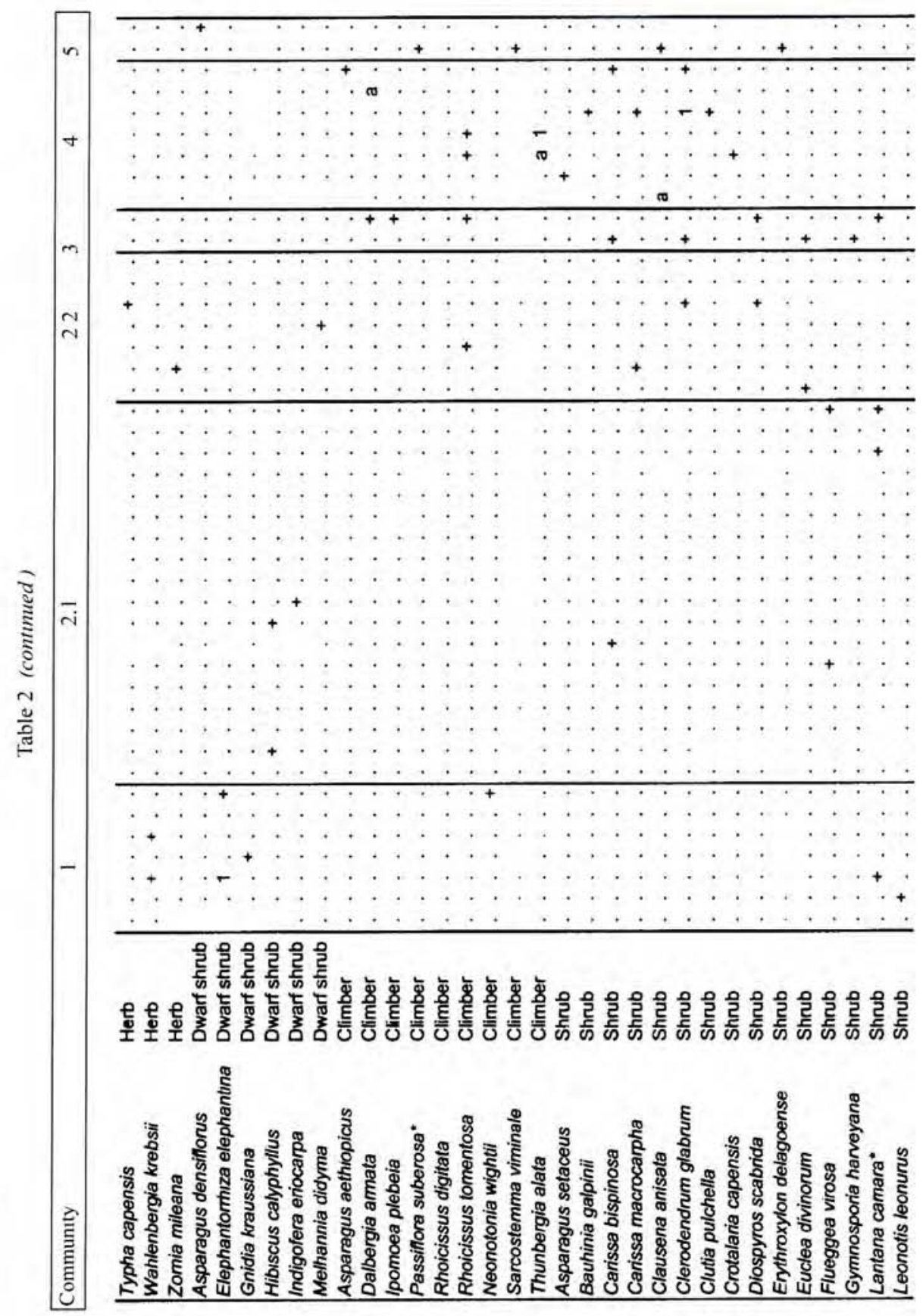




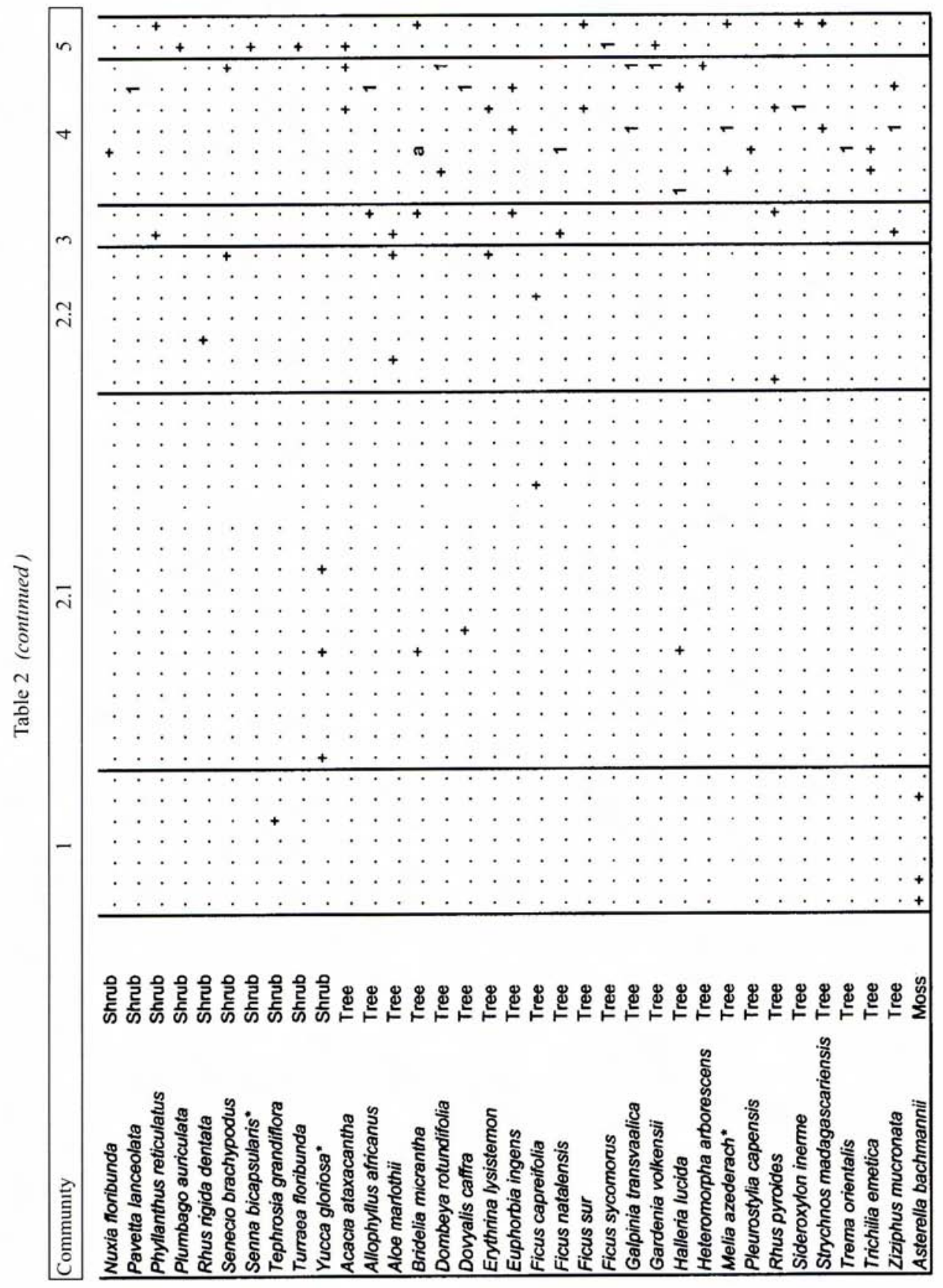




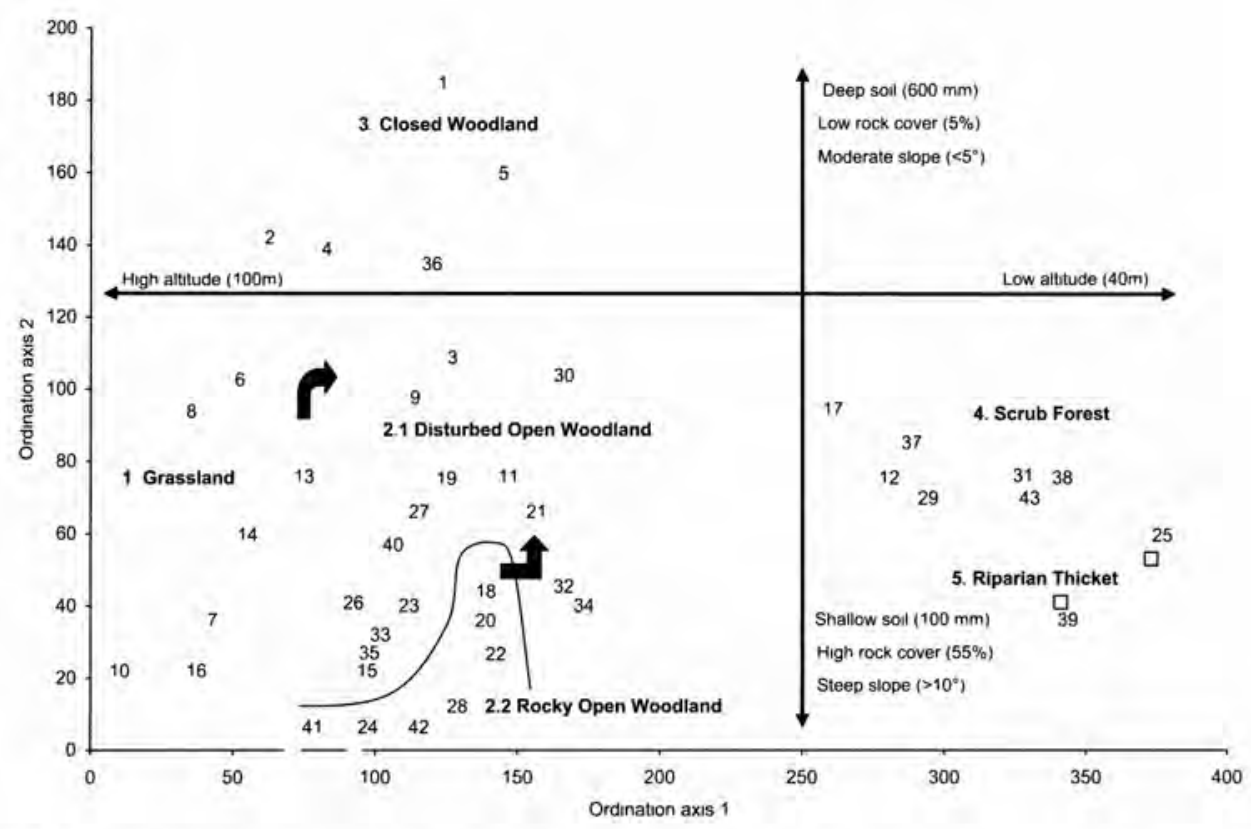

Fig. 3. Relatıve positıons of all relevés along the first and second axıs of an ordınation. Plant community numbers correspond with those in the text and Table 2.

olus vernus and Hypoxis hemerocallidea. The vegetation is dominated by grasses that occur in dense stands on previously cultivated areas and pastures, with only a few woody species present. Dominant grass species include Eragrostis curvula, Hyparrhenia hirta, Setaria nigrirostris, Themeda triandra and Tristachya leucothrix (species groups E and G). Cymbopogon nardus dominates the margins of shrubby bush clumps, which are dominated by Acacia karroo, A. nilotica and Dichrostachys cinerea (species group $\mathrm{O}$ ). The high diversity and total species richness of this community (Fig. 4) can possibly be attributed to regular seasonal fires and the subsequent low canopy cover of woody species (Fig. 5).

\section{Diheteropogon amplectens-Phoenix reclinata Open Woodland}

This community covers the largest part of the study area. It stretches from the central parts of the farm, from between the Nseleni and Cwaka Rivers to the eastern and northern borders where it gradually merges with the surrounding vegetation on the land of subsistence farmers. The dominant soil type is the Mayo form, which ranges from $100 \mathrm{~mm}$ in depth on steep rocky slopes to $300 \mathrm{~mm}$ on the plains (Table 3). Most of the plains were cultivated during the 1940s and early 1950s, whereas no cultivation took place on the steep rocky hills where grazing and fire is also less common.

This open woodland community is characterised by the diagnostic taxa presented in species group B (Table 2). The list includes grass species such as Diheteropogon amplectens and Trachypogon spicatus, forb species such as Kalanchoe rotundifolia and Solanum panduriforme, and tree/shrub species such as Diospyros simii, Euclea undulata and Phoenix reclinata (palm). On previously cultivated lands, Acacia karroo 
and A. nilotica (species group $\mathrm{O}$ ) occur in moderately closed bush clumps. Palatable grasses have a high cover percentage (Table 2) and give this community the highest grazing value at OSCA (Table 3).

This community was classified into two prominent sub-communities, which differ in soil depth, slope and frequency of man induced disturbances such as grazing, cultivation and fire.

\subsection{Chloris gayana-Schinus terebinthifolius Disturbed Open Woodland}

This sub-community occurs on open, flat, previously cultivated (1940-1950) and overgrazed (1960 to present) areas on the northern and eastern parts of the farm. Overgrazing is especially evident in the areas sur- rounding farm dams. Remains of old kraals are common in some areas. Alien species such as the invasive Schinus terebinthifolius and Yucca gloriosa served as hedges/fences around the kraals and are still abundant in this plant community. Soil depths range from 200-300 mm, with clay content between $45 \%$ and $70 \%$ (Table 3 ). Uncontrolled fires, which probably originated from the adjacent farms, were a common phenomenon in this community before 1980 , after which firebreaks were implemented.

This disturbed woodland is characterised by the diagnostic taxa listed in species group $\mathrm{C}$ (Table 2). The plant community is rich in grass diversity and dominant species include Chloris gayana, Cymbopogon nardus, Diheteropogon amplectens, Eragrostis

Table 3

Environmental factors and selected attributes associated with the different plant communties of OSC $A$

\begin{tabular}{|c|c|c|c|c|c|c|}
\hline \multirow[t]{2}{*}{ Factors/attributes } & \multicolumn{6}{|c|}{ Plant communities } \\
\hline & 1 & 21 & 2.2 & 3 & 4 & 5 \\
\hline Number of relevés & 7 & 18 & 7 & 2 & 7 & 2 \\
\hline Mean species per relevé & 45 & 35 & 43 & 59 & 32 & 42 \\
\hline Total number of species & 127 & 112 & 112 & 89 & 96 & 62 \\
\hline Trees & 5 & 18 & 17 & 17 & 38 & 23 \\
\hline Shrubs & 9 & 18 & 19 & 15 & 25 & 16 \\
\hline Dwarf shrubs & 5 & 4 & 2 & 1 & 1 & 2 \\
\hline Clımbers & 4 & 5 & 5 & 8 & 10 & 7 \\
\hline Herbs & 60 & 27 & 34 & 25 & 14 & 6 \\
\hline Geophytes & 18 & 9 & 8 & 6 & 4 & 6 \\
\hline Annuals & 4 & 7 & 4 & 3 & 1 & 0 \\
\hline Grasses & 22 & 24 & 23 & 14 & 3 & 2 \\
\hline Hectares (ha) & 193 & 152 & 89 & 101 & 69 & 68 \\
\hline Grass cover $(\%)$ & 28 & 30 & 28 & 25 & 1 & 1 \\
\hline Forb cover $(\%)$ & 11 & 5 & 6 & 8 & 3 & 4 \\
\hline Woody cover $(\%)$ & 10 & 29 & 26 & 44 & 86 & 77 \\
\hline Grazing value (LSU ${ }^{1 / 10 h a)}$ & 4 & 5 & 6 & 4 & 2 & 2 \\
\hline Altitudinal range $(\mathrm{m})$ & $75-95$ & $50-110$ & $40-120$ & 80 & $40-95$ & $65-90$ \\
\hline Slope $\left({ }^{\circ}\right)$ & $5-6$ & $5-8$ & $10-13$ & 4-8 & $6-12$ & $10-16$ \\
\hline Aspect $^{2}$ & $\mathrm{~S} ; \mathrm{E}$ & $\mathrm{E} ; \mathrm{S}$ & $\mathrm{W} ; \mathrm{S}$ & $\mathrm{E} ; \mathrm{N}$ & W; S & $\mathrm{N} ; \mathrm{E}$ \\
\hline Dominant soll form ${ }^{3}$ & My & My: Gs & My & My; Ik & $\mathrm{Oa} ; \mathrm{Ik}$ & Gs \\
\hline Soll depth (mm) & $100-180$ & $200-330$ & $100-170$ & $250-625$ & $400-800$ & $350-400$ \\
\hline Rock cover $(\%)$ & $20-40$ & $0-40$ & $40-50$ & $0-10$ & $20-30$ & $50-60$ \\
\hline Mean radiation index & 2.5 & 2.9 & 2.9 & 3.5 & 2.4 & 4 \\
\hline
\end{tabular}


curvula, Hyparrhenia hirta, Setaria nigrirostris, $S$. sphacelata. Themeda triandra, and Tristachya leucothrix (species groups B, C, E, G). Prominent forb species include Scabiosa columbaria, Helichrysum nudifolium and the geophyte, Hypoxis hemerocallidea (species groups $\mathrm{G}$ and $\mathrm{K}$ ). The woody layer is well developed and has a canopy cover of up to $30 \%$. Besides the microphyllous thorn species, Euclea racemosa, E. undulata, Lippia javanica, Phoenix reclinata, Scutia myrtina and Rhus rehmanniana (species groups $\mathrm{B}, \mathrm{G}, \mathrm{N}$ and $\mathrm{O}$ ) are abundant. Naturalised alien trees from tropical American are aggressively invading this community, and include Chromolaena odorata, Schinus terebinthifolius and Psidium guajava. Invaders are associated with dense bush clumps of Acacia nilotica. Diospyros simii, Gymnosporia buxifolia and Coddia rudis (species groups $\mathrm{B}$ and $\mathrm{N}$ ) occur as small shrubs due to frequent fire and grazing damage.

\subsection{Trachypogon spicalus-Gymnosporia bux- ifolıa Rocky Open Woodland}

This sub-community is strongly associated with moderately steep, rocky hills in the western parts of the study area (Table 3 ). Soils are shallow $(100-150 \mathrm{~mm})$, with underlying loose rocks. Human-induced disturbances are less frequent in this inaccessible sub-community due to slope and rockiness, although old kraals are present.

Diagnostic species are listed in species group D (Table 2) and include woody species such as Gymnosporia buxifolia and Sclerocarya birrea. The geophytes Bulbine abyssinica and Schizocarpus nervosus, which are typically associated with rocky outcrops, are the only diagnostic forbs in this community. Other prominent species include Diospyros lycioides, Euclea undulata, Gymnosporia senegalensis and Kraussia floribunda (species groups $\mathrm{B}, \mathrm{N}$ and $\mathrm{O}$ ) in the woody layer and Polygala leendertziae and Scabiosa columbaria (species groups $E$ and $G$ ) in the herbaceous layer. The woody canopy cover is up to $25 \%$, although the cover is higher in areas near the old kraals that date from the early 1940s. Hyparrhenia hirta and Eragrostis curvula (species group G) cover large areas of previously cultivated and disturbed areas. Better management (less frequent fires and overgrazing) of the grass layer of rocky slopes resulted in a high cover percentage (Fig. 5) of Decreaser species such as Dactyloctenium australe, Digitaria eriantha, Diheteropogon amplectens, Panicum maximum, Setaria nigrirostris, S. sphacelata and Themeda triandra (species groups B and G).

3. Acacia nilotica-Lantana rugosa Closed Woodland

Although only two relevés were classified here (Table 2), it is a distinct community that occurs on deep, wet soils and abandoned cultivated fields of the eastern parts of the study area (Table 3). This community was burnt regularly until the late 1990s. For the past seven years no fire occurred in this community due to longer lasting green foliage in the grass layer during winter months, caused by high soil moisture. Vegetation cover in this woodland community is high (approximately $75 \%$ ) and the area is not heavily utilised by livestock as they prefer the more palatable grasses of the adjacent open plains.

Species diagnostic for this community are listed in species group $\mathrm{F}$ (Table 2), which include the South American grass Paspalum dilatatum, forb species such as Ruellia cordata. Aster bakerianus, and small shrubby Lantana rugosa. Other conspicuous forb species include Cycnium adonense, Freesia laxa and Thunbergia dregeana (species groups I and K). Prominent woody species include Gymnosporia senegalensis, Kraussia floribunda, Lippia javanica and Euclea racemosa (species groups $\mathrm{K}, \mathrm{N}$ and $\mathrm{O}$ ). Dense stands of Acacia karroo, A. nilotica and Dichrostachy's cinerea occur frequently, although most of the individuals are juveniles, which indicate potential bush encroachment. Climbers are common and include Cissampelos torulosa and Rhoicissus tridentata. The climbing nature of the invasive scrambling shrub Chromolaena odorata has resulted in dense canopies in bush clumps dominated by Acacia nilotica. 


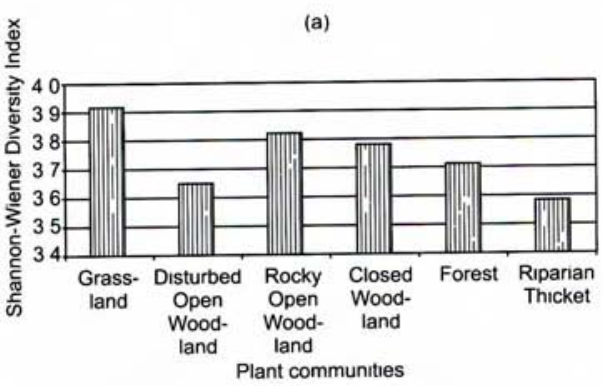

(b)

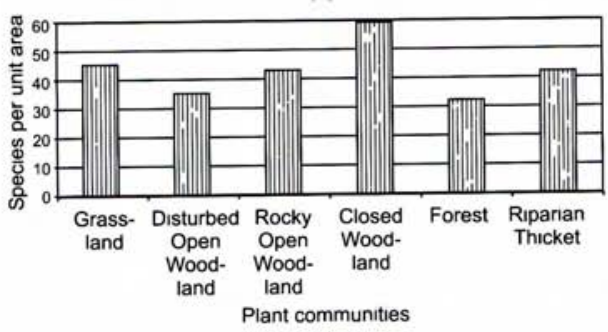

(c)

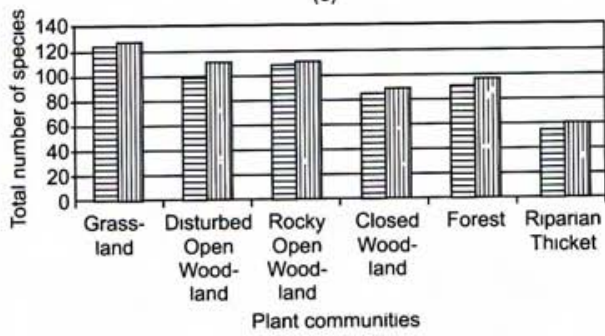

Fig. 4. Analysis of species diversity and richness of the plant communities of OSCA: (a) ShannonWiener Diversity Index, (b) mean species richness per unit area, and (c) total species richness (horızontal bars = total - alien taxa).

Many of the dominant grass species of this community indicate previous disturbance, e.g. old fields, and include Bothriochloa insculpta, Cymbopogon excavatus, Eragrostis curvula and Hyparrhenia hirta (species groups G). Other dominant grass species include Digitaria eriantha and Paspalum dilatatum (species groups $\mathrm{F}$ and $\mathrm{G}$ ), which are generally associated with moist soils. Species richness per unit area of this community is the highest for the study area (Fig. 4).
B. Acacia karroo-Hippobromus paucıflorus Closed Coastal Thornveld

This closed vegetation type is confined to lower lying areas along drainage lines and floodplains of the Cwaka and Nseleni Rivers. Soils are deep with high moisture content (Table 3). It is the least disturbed area on OSCA, as this area was not extensively cultivated or grazed due to steep slopes and burning stopped in the late 1960s. Recent years have seen aggressive invasions by alien plant species. This vegetation type can therefore be considered as a natural, advanced successional type, probably representing a sub-climax between thornveld and forest. The vegetation belongs to Moist Coast Forest and Thornveld (Camp 2001).

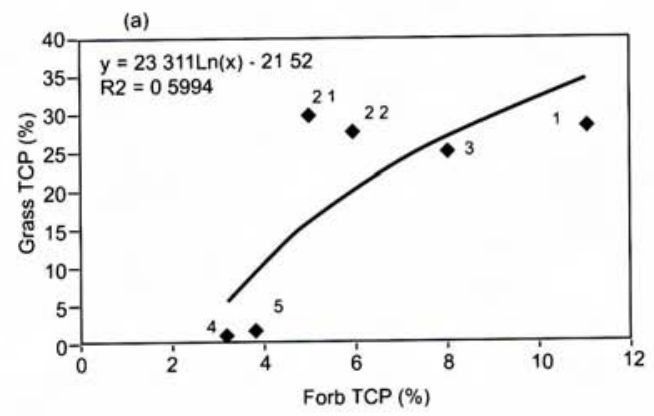

(b)

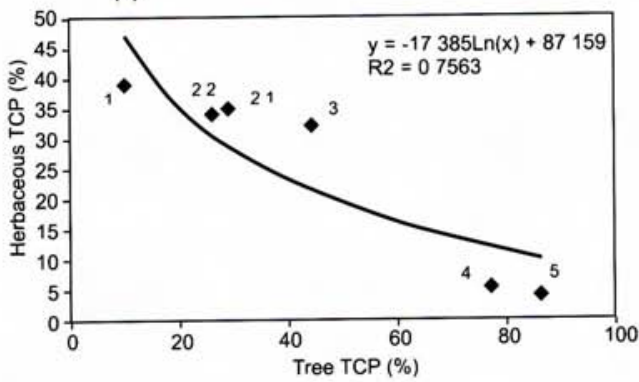

Fig. 5. Total Cover Percentage (TCP) for selected growth forms, as a function of co-existence in each plant community: (a) grass TCP plotted against forb TCP, and (b) herbaceous (forbs + grasses) TCP plotted against tree TCP. 
This vegetation type is differentiated from the Acacia karroo-Themeda triandra Open Coastal Thornveld by the near-absence of grass cover (Fig. 5) and the presence of many different broad-leaved woody species and climbers. It is characterised by the diagnostic taxa listed in species group M (Table 2), which include the shrubs Grewia occidentalis and Hippobromus pauciflorus, and the trees Apodytes dimidiata, Euphorbia tirucal$l i$ and Trichilia dregeana. Broad-leaved species specifically associated with deep, moist soils characterise the community, but the most dominant trees are microphyllous species. Chromolaena odorata infestation is severe in this vegetation type. This vegetation type has the lowest diversity and species richness in the study area (Fig. 4).

\section{Asparagus falcatus-Trimeria grandifolıa Scrub Forest}

This forest community occurs on moderately sloped to flat terrain in the western part of the study area on the banks of the major rivers (Table 3 ). It is associated with a variety of soil types, which include Mayo, Inhoek, Oakleaf and Shortlands. Soil depth range from $300-800 \mathrm{~mm}$. Variation in soil depth and type gave rise to much diversity in local floristic composition. Patches of this community was previously cultivated and grazed. Since the 1980 s this wooded community was not burnt, which may explain the development of a forest type.

Although the plant community is dominated by a rich diversity of woody taxa with a high canopy cover $(80 \%)$, only the tree Trimeria grandifolia and climber Asparagus falcatus (species group $\mathrm{H}$ ) are diagnostic species (Table 2). Microphyllous species such as Acacia karroo, A. nilotica, A. robusta and Dichrostachys cinerea (species group O) dominate the community, but many different broadleaf species also occur. These include Apodytes dimidiata, Euclea racemosa, Grewia occidentalis, Hippobromus pauciflorus, Kraussia floribunda, Olea europaea, Trichilia dregeana and Vangueria infausta (species groups $\mathrm{M}, \mathrm{N}$ and $\mathrm{O}$ ). Although various creepers (ten taxa) are found within this community, the scrambling Jasminum multi- partitum, Senecio tamoides and extremely invasive Chromolaena odorata are dominant in certain parts (species group N). The scandent shrub Scutia myrtina forms dense canopies in some of the higher trees. Dense woody cover inhibits grass species to proliferate resulting in low grass species diversity and cover (Fig. 5). Conspicuous forbs include various members of the Acanthaceae, such as Barleria obtusa, Justicia flava and Thunbergia dregeana (Species groups I, J and O).

\section{Commiphora harveyt-Cussonia zuluensis Rıpanan Thıcket}

This community is typically associated with steeper slopes along the Nseleni River and along the western part of the farm. The main soil form is Glenrosa with a soil depth of $300-400 \mathrm{~mm}$ and underlying rocks (Table 3 ). This community was not previously cultivated and was excluded from fire and grazing since the $1980 \mathrm{~s}$. It therefore represents a natural, late successional community. Although only two relevés are presented here, its composition of diagnostic species clearly distinguishes it as a unique community of lithophyllic vegetation.

This thicket is characterised by the nearabsence of grass species and the presence of the diagnostic species in species group $\mathrm{L}$ (Table 2), of which Commiphora harveyi and Aloe rupestris are the most conspicuous. Geophytes such as Eucomis autumnalis, Sansevieria hyacinthoides and Scadoxus puniceus are prominent diagnostic species. Microphyllous species dominate the tree layer, but are interspersed by conspicuous broadleaf species such as Apodytes dimidiata, Coddia rudis, Cussonia zuluensis, Erythrina caffra, Dombeya burgessiae, Euclea racemosa and Hippobromus pauciflorus (species group L, M, N and O). This thicket has a woody canopy cover of nearly $80 \%$ (Fig. 5). As in the Scrub Forest, climbers are common, such as Jasminum multipartitum and Pisonia aculeata. Dense infestation by the alien invasive species, Chromolaena odorata and Passiflora suberosa, occurs occasionally. Riparian Thicket has a lower 
diversity and total species richness than Scrub Forest, but has higher species richness per unit area (Fig. 4).

\section{Ordination}

An ordination illustrated that the distribution of plant communities of OSCA follows the gradients of specific environmental factors (Fig. 3). The distribution of relevés along the first and second axes of a scatter diagram (Fig. 3) corresponds to variation in soil depth, slope, rockiness and elevation. Vegetation is correlated with an elevation gradient along the first axis (eigen value $=0.458$ ), and soil depth, slope and rockiness correlate with a vegetation gradient depicted by the second axis (eigen value $=0.193$ ). Plant communities are arranged along the first axis according to an altitudinal gradient, with Acacia karroo-Themeda triandra Open Coastal Thornveld of higher lying slopes and plateau on the left and Acacia karroo-Hippobromus pauciflorus Closed Coastal Thornveld of low-lying valleys on the right. Along the second axis, communities of moist environments, i.e. deep soils, lie in the upper half of the diagram. Communities of dry, rocky, steep slopes are in the bottom half. Soil depth and rock cover in turn relates to water retention and drainage of habitat. Both riparian and highland areas have a general gradient of (i) deep, moist soils with low rock cover and moderate slope, to (ii) shallow, drier soils with high rock cover and steep slope.

Land-use history, especially cultivation, fire and grazing, are usually associated with certain physical environmental factors. It is likely that a combination of land-use and environmental factors has driven differentiation in floristic composition of the study area's vegetation over the past 75 years (Van der Linden 2004). This is more so for higher lying, accessible areas than for wooded areas near rivers and drainage lines. In these areas unpredictable land-use practices, in combination with natural environmental factors, have resulted in a heterogeneous floristic composition that has made the identification of clear-cut sub-communities difficult. However, from the scatter diagram it does seem as if Disturbed Open Woodland can be further divided, namely communities that originate when either Grassland or Rocky Open Woodland is disturbed (Fig. 3; black arrows indicate possible successional pathway).

\section{Vegetation structure}

To illustrate the difference in structure of the plant communities of OSCA, current relationships between the tree cover and herbaceous layer are plotted (Fig. 5). Co-existence graphs of these growth forms depict the state of the grass-forb-tree relationship. Briske \& Hendrickson (1998) ascribed changes in vegetation structure as a result of over-utilization as an ecological response to minimise the effect of selective grazing/harvesting. Co-existence graphs of growth forms illustrate the degree of structural change and can be applied to monitor the state of a plant community by comparing annual trends.

The trend depicted in Fig. 5a is that of coexistence, because as the total cover percentage (TCP) of the grass layer increases, the forb TCP also increases. This linear increase in biomass production is probably due to competition for available solar radiation. On the left of the graph, both grass and forb TCP is below $5 \%$, probably because the herbaceous layer is outcompeted by trees for sunlight and are sparsely scattered in the understorey where filtered light reaches the soil. On the right hand side of the graph, both grass and forb TCP have increased six times in full sun, with grasses being the most dominant. Figure $5 \mathrm{~b}$ illustrates the relationship between tree cover and herbaceous layers. TCP of the herbaceous layer is lowest $(<10 \%)$ on the right of the graph where tree TCP is at its highest levels (>75\%). On the left of the graph, herbaceous TCP increases to over $30 \%$ when tree TCP decreases below $50 \%$. When considering the preservation of smaller flowering plants, the optimum condition for co-existence would be a tree TCP of approximately $50 \%$, which would allow the herbaceous layer to attain a maximum 
TCP. Short, open woodland could therefore be the ideal vegetation structure to support optimal, by protecting the soil and providing enough light penetration for forbs and grasses.

\section{Phytodiversity}

Grassland and Rocky Open Woodland communities $(1 \& 2.2)$ have the highest total species richness (Fig. 4c). In contrast, Riparian Thicket (5) has the lowest indigenous species richness. Mean species richness per unit area of Closed Woodland (3) is the highest for the study area, but this is probably distorted by the low sample intensity, i.e. two relevés (Fig. 4b). However, it still compares better ( 59 species/relevé) than the richest woodland in northern KwaZulu-Natal (48 species/relevé) recorded by Eckhardt et al. (1997). Mean species richness of Grasslands is the second highest at OSCA, and of the same level as Rocky Highveld Grassland (Smit et al. 1997). However, it has a higher diversity index (Fig. 4a) than any grassland community of the Rocky Highveld Grassland, which is generally regarded as the most diverse grassland vegetation type in South Africa. The same can be said for tree-dominated communities at OSCA when compared with similar communities of Rocky Highveld Grassland. Only Disturbed Open Woodland and Riparian Thicket do not compare well, as these plant communities are dominated by only a few species which contribute to a lower diversity index (Fig. 4a).

It is clear from the above that the plant diversity and richness of certain communities has remained high despite regular changes in land-use that altered the species assemblages. This is best explained by the conversion from grassland to disturbed savanna, which is mediated by the invasion of microphyllous woody plants, in particular Acacia species (Higgins et al. 1999). The resulting tree cover facilitates the establishment of species of later succession, particularly bird dispersed fruits of broad-leaved woody plants and succulents (Thrash 1998; Cooke \& Johnson 2002). This means richness and diversity decreases after a disturbance, but then stabilises and increases when succession occurs. In the study area this is supported by the high plant diversity of Closed Woodland, which seems to be the next successional stage after Disturbed Open Woodland (Fig. 3). Currently, the ordination does not depict any progressive change towards forest. Although the grasslands are the most diverse and species rich, the successional stages tend toward woodland after a disturbance, suggesting that grasslands of OSCA are maintained by fire.

\section{Fire}

Migrating tribes along the Mozambique coastal plain were probably the first people to markedly influence the ecology of the eastern parts of KwaZulu-Natal (Hall 1976). According to Hall (1984), these people were semi-permanent agriculturists, who used fire to clear forested areas for fields and grazing. The long history of fires and the adaptations of vegetation to withstand fire indicate that it is a natural and controlling ecological factor in some of the grassland, woodland and forest areas of southern Africa, which include the northern parts of KwaZulu-Natal (Tainton \& Mentis 1984). Although the effects of fire on climax highland sourveld grasslands have been well researched, less has been done on the sour-mixed coastal grasslands of the Maputaland Coastal Plain (Siebert et al. 2004), or on the transitional area within which OSCA falls (Van der Linden 2004).

In the transitional area it is unclear what the climax state of grasslands should be, as plant species composition and vegetation structure was driven by different fire regimes. Before 1960 , fire was controlled by pastoralists, from the late 1960 s to early 1990 s by a burning programme, and since 1990 burning events became erratic and unpredictable. This resulted in new successional pathways, as the next burning event took place before the vegetation could recover from the previous burn. Erratic burning somehow created favourable conditions for the regeneration and establishment of microphyllous species, 
such as Dichrostachys cinerea, Acacia karroo and $A$. nilotica. Plant communities of Open Coastal Thornveld therefore consist of a mosaic of different seral stages of vegetation that gradually merges, and is grouped and classified under Grassland, Open Woodland and Closed Woodland. This is supported by aerial photographs that show drastic changes in vegetation structure over the past 70 years (Van der Linden 2004).

\section{Bush encroachment}

Different management practices at OSCA have led to the development of secondary plant communities and fragmentation of the natural vegetation. The interplay between disturbance and ecological processes, such as intensive grazing and regular fires, accounted for a major portion of the organization and spatial patterning of natural communities in the study area. Classification of the current vegetation patterns indicates that different management practices since 1960 modified the vegetation structure even further, which resulted in bush encroachment. This occurrence of periodic disturbance ensured continuing shifts in plant species composition. Disturbance after disturbance resulted in bursts of regeneration that, once established, suppressed progressive succession. This is especially apparent in the Acacia nilotica-Lantana rugosa Closed Woodland that was regularly cultivated and burnt. Most of the woody species occur as juveniles, which poses a bush encroachment threat.

High abundance of microphyllous species, such as Acacia karroo, A. nilotica and Dichrostachys cinerea (species group $\mathrm{O}$, Table 1) over the entire study area indicate a dynamic shift in vegetation structure, consequently leading to losses of natural grassland communities. In turn, these newly established woodlands become invaded by alien plant species and these seedbanks pose a serious threat to the maintenance of plant species diversity in near future (Van der Linden 2004). From the DECORANA it is clear that Grassland and Rocky Open Woodland communities become Disturbed Open Woodland after ploughing or overgrazing (Fig. 3). This disturbed woodland then steadily undergoes bush encroachment to become Closed Woodland. This seral stage could possibly develop into Scrub Forest over time ( $>50$ years).

\section{Conservation}

Although OSCA is relatively small, its heterogenous topography and consequently large variety of habitats harbour a considerable richness of plant species of various life forms (Table 2; Fig. 4). The plant communities are, however, constantly changing in response to different disturbance events. High infestation of alien invasive species, such as Chromolaena odorata, Schinus terebinthifolius and Psidium guajava poses a major threat to the maintenance of the biodiversity on OSCA. Chromolaena odorata, a declared category 1 weed (Henderson 2001), occurs in high abundances in all plant communities, although the Asparagus falcatusTrimeria grandifolia Scrub Forest and Commiphora harveyi-Cussonia zuluensis Riparian Thicket are the most affected by its scrambling habit that smothers the indigenous canopy. Psidium guajava, a category 2 invader species, and Schinus terebinthifolius, a category 1 weed (Henderson 2001), are common in the Diheteropogon amplectensPhoenix reclinata Open Woodland and need to be eradicated to maintain the high species richness of this fragmented vegetation type. An action plan for the control of alien invasive species is required, since ignorance could lead to species losses on the farm. Two plant communities are of special concern:

i) A few natural areas of coastal grasslands exist, and most of the remnants are fragmented and disturbed. The question arises as to whether it is a viable option to preserve such relatively small areas. OSCA grassland contains a high richness of traditional and medicinal plants (Van der Linden 2004) and should therefore be considered as a genebank for these bioresources. The plant communi- 
ties, although disturbed and seral, maintain these resources and should be conserved.

ii) The Scrub Forest of the study area is floristically related to the Plectrantho fruticosi-Trimerietum grandifoliae (Eckhardt et al. 1997), a plant community regarded as threatened. It was first described from areas along the upper reaches of the Black Mfolozi. OSCA serves as a refuge for this plant community and should, together with the last remaining grasslands, be highlighted as a priority for conservation efforts and sustainable management practices.

\section{Conclusions}

The TWINSPAN classification and subsequent refinement by Braun-Blanquet procedures resulted in the delineation of five plant communities. These communities were related to certain environmental factors, the gradients which are depicted in a DECORANA scatter diagram. Soil depth, rock cover, slope and elevation are the major determinants of the species assemblages of the communities. Different events related to land-use history and current management practices, such as old fields, grazing and fire, determine the current vegetation structure and occurrence of plant communities on OSCA farm. Despite years of disturbance at OSCA, grassland and woodland communities have maintained their diversity, and compare well with areas recognised for high species richness.

Description of the different vegetation units of OSCA farm makes a significant contribution towards the understanding of thornveld in the transitional area of Bushveld and Grassland in coastal areas. However, further detailed ecological studies need to be done on old fields of different ages to derive hypothetical succession pathways for future grazing management, and natural grassland regeneration needs to be investigated to develop sustainable management plans for natural resource harvesting. The integrity of the plant communities can be maintained by addressing alien invasion, bush encroachment and uncontrolled burning, to ensure that it remains a productive landscape.

\section{Acknowledgements}

Owen Sitole College of Agriculture and the Unıversity of Zululand financially supported this research. Anonymous referees are thanked for useful comments and suggestions that greatly improved the manuscript.

\section{References}

Acocks, J.P.H. 1988. Veld Types of South Africa. Memorrs of the botanical Survey of South Africa 57: 1-146.

Agromet. 2002. Zululand climate report Unpublished report. Institute for Soll, Climate and Water.

BARBOL'R, M.G., J.H. BLRK \& W.D. PIITS. 1987. Terrestrial plant ecology. Calıforna: Cummıngs.

BRISKE, D.D. \& J.R. HENDRICKSON. 1998. Does selectıve defoliation mediate competitıve interactions in a semiarid savanna? A demographic evaluation. Journal of Vegetation Science 9: 611-622.

BRLUN, H.H. 2000. Deficit in community species richness as explained by area and isolation of sites. Diversity and Distributions 6: 129-135.

Camp, C. 1997. The Bioresource Groups of KwaZulu-Natal. Pietermaritzburg: Cedara Natural Resource Section. (Internal Report No. N/A/97/6).

COOKE, J.A. \& M.S. JOHNSON. 2002. Ecological restoration of land with particular reference to the minıng of metals and industrial minerals: A review of theory and practise. Environmental Reviews 10: 41-71.

ECKHARDT, H.C., N. VAN ROOYEN \& G.J. BREDENKAMP. 1997. Plant communities of the forests, woodlands and thickets in northern KwaZuluNatal. Koedoe 40: 91-112.

EDWARDS, D. 1983. A broad-scale structural classification of vegetation for practical purposes. Bothalia 14: 705-712.

Foran, B.D., G. Basirn \& K.A. Shaw. 1986. Range assessment and monitoring in arid lands: The use of classification and ordination in range survey. Journal of Environmental Management 22: 67-84.

Germishlizen, G. \& N.L. Meyer. 2003. Plants of southern Africa: an annotated checklıst. Pretorıa: National Botanıcal Institute. (Strelitzıa 14)

Goodman, P.S., B. James \& L. Carlisle. 2002. Wildlife utilization: its role in fosterıng bıodi- 
versity conservation in KwaZulu-Natal. Pp. 2131. In Pierce, S.M., R.M. CoWling, T. SANDWITH \& K. MACKINNON (eds). Mainstreaming biodiversity in development. Washington, DC: The World Bank.

Granger, E., G.J. Bredenkamp \& N. van Rooyen. 1996. Coastal Bushveld-Grassland. Pp. 30-31. In Low, A.B. \& A.G. ReBelo (eds). Vegetation of South Africa, Lesotho and Swazland. Pretoria: Department of Environmental Affairs \& Tourism.

HALl, M. 1976. Dendroclımatology, rainfall and human adaptation in the later Iron Age of Natal and Zululand. Annals of the Natal Museum 22: 693-703.

HALL, M. 1984. Man's historical and traditional use of fire in southern Africa. Pp. 39-52. In BooySEN, P. DE V. \& N.M. TAINTON (eds). Ecological effects of fire in South African ecosystems. New York: Sprınger-Verlag. (Ecological Studies 48).

Henderson, L. 2001. Alien weeds and invasive plants. Pretoria: Agricultural Research Council. (Plant Protection Research Institute Handbook 12)

HenNekens, S. 1996a. TL'RBOVEG Software package for input, processing, and presentation of phytosocıological data L'ser's guıde. Lancaster: Unıversity of $\mathrm{L}$ ancaster. IBN-DLO.

HeNNEKENS, S. 1996b. MEGATAB A visual editor for phytosociological tables Version 10 L'ser's guide. Ulft: Giesen \& Geurts.

Higgins, S.I., C.M. Shackleton \& E.R. Robinson. 1999. Changes in woody community structure and composition under contrastıng landuse systems in a semi-arid savanna, South Africa. Journal of Biogeography 26: 619-627.

HIL., M.O. 1979a. TWINSPAN - a FORTRAN program for arranging multwariate data in an ordered two way table by classification of indlviduals and attributes New York: Cornell Unıversity, Ithaca.

HiLl. M.O. 1979b. DECORANA - a FORTRAN program for detrended correspondence analysis and reciprocal averaging New York: Cornell University, Ithaca.

Hughes, G.R. 2002. Democratısation: Biodiversity conservation for all people - a case study from KwaZulu-Natal. Pp. 67-77. In: PIERCE, S.M., R.M. Cowl.ING, T. SANDWITH \& K. MacKinNoN (eds.). Mainstreaming biodiversity in development. Washington: The World Bank.

Hutchings, A. 1996. Zulu medicınal plants. Pietermaritzburg: Natal Unıversity Press.

Kent, M. \& J. BALLARD. 1988. Trends and problems in the application of classification and ordination methods in plant ecology. Vegetatıo 78: 109-124.

Mueller-Dombois, D. \& H. EllenberG. 1974. Alms and methods of vegetation ecology New York: Wiley.
Roberts, D., M. MANder \& R. BoON. 2002. An urban challenge: Conserving biodiversity in the Ethekwını Munıcıpalıty, KwaZulu-Natal. Pp. 79-87. In: PIERCE, S.M., R.M. COWling, T. SANDWITH \& K. MACKINNON (eds.). Mainstreaming biodiversity in development Washington: The World Bank.

Scort-SHAw, R. 1999. Rare and threatened plants of KwaZulu-Natal and neighbouring regıons $a$ plant red data book. Cascades: KwaZulu-Natal Nature Conservation Services.

Siebert, S.J., L. Fish, M.M. UiRAS \& S.A. IZIDINE. 2004. Grass assemblages of conservation areas of the coastal plain south of Maputo Bay, Mozambique. Bothalıa 34: 61-71.

Sifbert, S.J., M. Matthee \& A.E. van Wyk. 2003. Semı-arıd savanna of the Potlake Nature Reserve and surrounding areas in Sekhukhuneland, South Africa. Koedoe 46: 29-52.

SMit, C.M., G.J. BREdenkamp, N. van RoOyen, A.E. VAN WYK \& J.M. COMBRINCK. 1997. Vegetation of the Witbank Nature Reserve and its importance for conservation of threatened Rocky Highveld Grassland. Koedoe 40: 85-104.

TAINTON, N.M. \& M.T. MENiIs. 1984 Fire in grassland. Pp. 115-147. In: BooyseN, P. DE V. \& N.M. TAINTON (eds). Ecological effects of fire in South African ecosystems. New York: Springer-Verlag. (Ecological Studies 48)

Thrash, I. 1998. Association of three succulent plant species with woody canopy in the mixed bushveld, South Africa. Koedoe 41: 95-101.

VAN DER LINDEN, J.P. 2004. Vegetation analysis of Owen Sitole Agricultural College campus, KwaZulu-Natal, South Africa. MSc thesis, Unıversity of Zululand, KwaDlangezwa.

VAN WYK, B-E. \& N. Gericke. 2000. People's plants $A$ guide to useful plants of southern Africa. Pretoria: Briza.

VisSER, D.J.L., F.J. COERTZE \& F. WALRAVEN. 1989. Explanation of the 11000000 geological map. fourth edition. 1984 The geology of the Republics of South Africa, Transker. Bophuthatswana, Venda and Ciskel and the Kingdoms of Lesotho and Swazıland. Pretoria: Government Printer.

Westhoff, V. \& E. VAN DER MAarel. 1978. The Braun-Blanquet approach. In: WHITTAKER, R.H. (ed.). Classification of plant communities. The Hague: Junk.

WhITTAKER, R.H. 1977. Evolution of species diversity in land communities. Evolutionary Bıology 10: 1-67.

With, K.A. \& A.W. KING. 1999. Extınction thresholds for species in fractal landscapes. Conservation Biology 13: 314-326. 